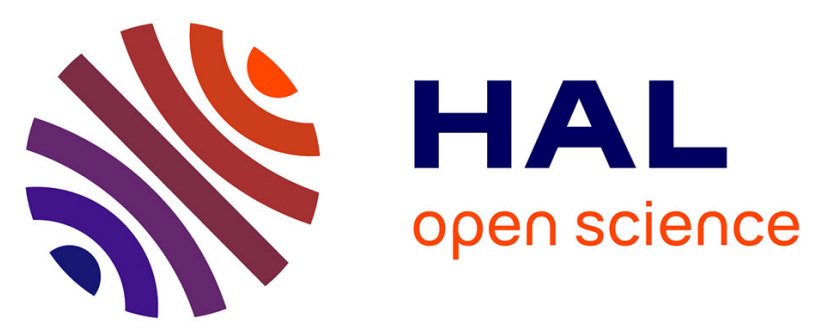

\title{
Identification of RHCE and KEL alleles in large cohorts of Afro-Caribbean and Comorian donors by multiplex SNaPshot and fragment assays: a transfusion support for sickle cell disease patients
}

Monique Silvy, Julie Di Cristofaro, Sophie Beley, Kassim Papa, Michel Rits, Pascale Richard, Chiaroni Jacques, Pascal Bailly

\section{To cite this version:}

Monique Silvy, Julie Di Cristofaro, Sophie Beley, Kassim Papa, Michel Rits, et al.. Identification of RHCE and KEL alleles in large cohorts of Afro-Caribbean and Comorian donors by multiplex SNaPshot and fragment assays: a transfusion support for sickle cell disease patients. British Journal of Haematology, 2011, 154 (2), pp.260. 10.1111/j.1365-2141.2011.08691.x . hal-00645380

\author{
HAL Id: hal-00645380 \\ https://hal.science/hal-00645380
}

Submitted on 28 Nov 2011

HAL is a multi-disciplinary open access archive for the deposit and dissemination of scientific research documents, whether they are published or not. The documents may come from teaching and research institutions in France or abroad, or from public or private research centers.
L'archive ouverte pluridisciplinaire HAL, est destinée au dépôt et à la diffusion de documents scientifiques de niveau recherche, publiés ou non, émanant des établissements d'enseignement et de recherche français ou étrangers, des laboratoires publics ou privés. 


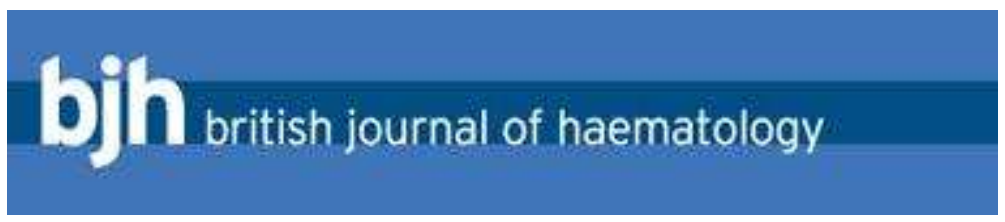

Identification of RHCE and KEL alleles in large cohorts of Afro-Caribbean and Comorian donors by multiplex SNaPshot and fragment assays: a transfusion support for sickle cell disease patients

\begin{tabular}{|c|c|}
\hline Journal: & British Journal of Haematology \\
\hline Manuscript ID: & BJH-2011-00181.R1 \\
\hline Manuscript Type: & Ordinary Papers \\
\hline $\begin{array}{r}\text { Date Submitted by the } \\
\text { Author: }\end{array}$ & 17-Mar-2011 \\
\hline Complete List of Authors: & $\begin{array}{l}\text { SILVY, Monique; Etablissement Français du Sang Alpes- } \\
\text { Méditerranée, Lab. d'Hématologie Moléculaire, UMR6578, Uni. de la } \\
\text { Méditerranée } \\
\text { DI CRISTOFARO, Julie; Etablissement Français du Sang Alpes- } \\
\text { Méditerranée, Lab. d'Hématologie Moléculaire, UMR6578, Uni. de la } \\
\text { Méditerranée } \\
\text { BELEY, Sophie; Etablissement Français du Sang, Lab. } \\
\text { d'Hématologie Moléculaire, UMR6578, Uni. de la Méditerranée } \\
\text { PAPA, Kassim; Etablissement Français du Sang Alpes-Méditerranée, } \\
\text { Lab. d'Hématologie Moléculaire, UMR6578, Uni. de la Méditerranée } \\
\text { RITS, Michel; Etablissement Français du Sang, Martinique } \\
\text { RICHARD, Pascale; Etablissement Français du Sang, Martinique } \\
\text { Jacques, CHIARONI; Etablissement Français du Sang Alpes- } \\
\text { Méditerranée, Lab. d'Hématologie Moléculaire, UMR6578, Uni. de la } \\
\text { Méditerranée } \\
\text { BAILLY, Pascal; Etablissement Français du Sang Alpes- } \\
\text { Méditerranée, Lab. d'Hématologie Moléculaire, UMR6578, Uni. de la } \\
\text { Méditerranée }\end{array}$ \\
\hline Key Words: & $\begin{array}{l}\text { BLOOD TRANSFUSION, MOLECULAR BIOLOGY, RED CELL } \\
\text { ANTIGENS, SICKLE CELL DISEASE }\end{array}$ \\
\hline
\end{tabular}


Identification of $R H C E$ and $K E L$ alleles in large cohorts of Afro-Caribbean and Comorian donors by multiplex SNaPshot and fragment assays: a transfusion support for sickle cell disease patients.

\author{
Monique Silvy, Julie Di Cristofaro, Sophie Beley, Kassim Papa, Michel Rits, Pascale Richard \\ Jacques Chiaroni and Pascal Bailly
}

From the Laboratoire d'Hématologie Moléculaire, Établissement Français du Sang Alpes Méditerranée, UMR 6578, Université de la Méditerranée, Marseille, and the Établissement Français du Sang, Fort de France, Martinique, France.

Corresponding author: Pascal Bailly, Laboratoire d'Hématologie Moléculaire, EFS Alpes Méditerranée, UMR 6578, Université de la Méditerranée, 207 Boulevard Sainte Marguerite, 13009, Marseille, France; Phone: 33-1-4-91-17-01-74; FAX: 33-1-4-91-17-01-78; E-mail: pascal.bailly@efs.sante.fr

Address reprint requests to: Pascal Bailly, Laboratoire d'Hématologie Moléculaire, EFS Alpes Méditerranée, UMR 6578, Université de la Méditerranée, 207 Boulevard Sainte Marguerite, 13009, Marseille, France; Phone: 33-1-4-91-17-01-74; FAX: 33-1-4-91-17-01-78; E-mail: pascal.bailly@efs.sante.fr

This study was supported by Établissement Français du Sang, Paris, France (all co-authors).

The authors declare that they have no conflict of interest in the subject matter of their manuscript. 


\begin{abstract}
To lower the alloimmunization risk following transfusion in blacks, we developed two genotyping assays for large-scale screening of Comorian and Afro-Caribbean donors. One was a multiplex SNaPshot assay designed to identify $c e^{s}(340), c e M O / A R / E K / B I / S M, c e^{s}$, $c e^{s}(1006)$ and $K E L * 6 / * 7$ alleles. The other was a multiplex fragment assay designed to detect $R H D, R H D \psi$ and $R H C E^{*} C$ and $455 \mathrm{~A}>\mathrm{C}$ transversion consistent with $(C) c e^{s}$ Type 1 and DIII Type $5 \mathrm{ce}^{\mathrm{s}}$.

Variant $R H C E^{*}$ ce alleles or $R H$ haplotypes were detected in $58.69 \%$ of Comorians and $41.23 \%$ of Afro-Caribbeans. The $c e^{s}$ allele, $(C) c e^{s}$ Type 1, and DIII Type $5 \mathrm{ce}^{\mathrm{s}}$ haplotypes were identified respectively in $39.13 \%, 14.67 \%$ and $4.88 \%$ of Comorians and $32.23 \%, 5.28 \%$ and $1.76 \%$ of Afro-Caribbeans. Genotypes consistent with partial D, C, c and/or e antigen expression were observed in $26.08 \%$ of Comorians and $14.69 \%$ of Afro-Caribbeans. No homozygous genotype corresponding to the RH:-18, -34, and -46 phenotypes were found. However, over $50 \%$ of genotypes produced low-prevalence antigens at risk for negative recipients, i.e., V, VS, JAL, and/or KEL6. One new variant $R H C E^{*} c e^{s}(712)$ allele was identified.

This is the first determination of variant RHCE and KEL allele frequencies. Results indicate most suitable targets for molecular assay screening to optimize use of compatible blood units and lower immunization risk.
\end{abstract}

\footnotetext{
Abstract $=200$ words

KEY WORDS: RHCE and KEL gene variants, SNaPshot, genotype, population with African origin.
}
AbBreviations: SNP(s) = single nucleotide polymorphism (s); bp = base pairs; $r f u(s)=$ relative fluorescence unit(s).




\section{INTRODUCTION}

The risk of post-transfusion alloimmunization increases with donor exposure and degree of donor/recipient red blood cell (RBC) antigen disparity (Higgins \& Sloan 2008). The risk is particularly high for minority racial groups such as persons of African descent living in Europe who harbor molecular variants compared to European blood donors (Aygun, et al, 2002; Daniels 2002; Noizat-Pirenne 2003). Sickle cell disease (SCD) patients undergoing long-term transfusion therapy have a higher risk of alloimmunization than the general population: 20 to $40 \%$ versus 5\% (Flickinger 2006). For SCD patients, alloimmunization has severe clinical consequences not only by increasing the difficulty of finding compatible blood but also by causing hemolytic transfusion reaction and autoantibody production and reducing the longevity of transfused RBCs (Aygun et al, 2002). Consistent with the fact that blacks harbor more molecular Rh variants than European blood donors (Avent \& Reid 2000), it has been observed that more than $60 \%$ of alloantibodies in SCD patients are directed against Rh antigens (Chou \& Westhoff 2009; Isaak, et al, 2006).

Two strategies that have been implemented in several countries to lower the incidence of alloantibody production in SCD patients, are extended Rh and Kell phenotype matching and intra-ethnic blood transfusions (Sosler et al, 1993; Wayne et al, 1993). Although these approaches seem to have positive effects to reduce alloimmunization (Vichinsky et al, 2001; Tahhan et al, 1994), it appears that some SCD patients still produce anti-D, -C , -c and -e despite having type $\mathrm{D}+, \mathrm{C}+, \mathrm{c}+$ and e+ RBCs respectively, that may be incorrectly classified as auto antibodies (Westhoff 2008). Indeed, molecular analysis of RHD, RHCE, KEL and $M N S$ genes in SCD patients has identified nucleotide polymorphisms showing that $\mathrm{Rh}, \mathrm{Kel}$ and Glycophorin B polypeptides differ from conventional amino-acid sequences indicating that serum antibodies are allo-type.

Three types of variant antigens are encountered : (i) absence of high-prevalence antigens resulting from homozygous alleles, haplotypes or gene deletion, (ii) partial antigens (c, e, C, D, $\mathrm{U}^{\mathrm{var}}$ ), and (iii) expression of low-prevalence antigens (see Table 1). These phenotypes are generally recognized once the allo-immunization is elicited against missing epitopes or when a transfusion reaction has occurred.

These antigen variants hardly recognized by current serological reagents, can be well identified by molecular tools. Despite this advance and different genotype reports on AfroCaribbean and African American black individuals notably with sickle cell disease, guidelines on the frequencies of variant $R H C E$ alleles and $K E L^{*} 6 / * 7$ alleles from large cohorts of 
African origin would be useful to prevent alloimmunization and improve transfusion therapy in countries with large African immigrant populations.

Our transfusion center is located in the southern French department of Bouches-duRhône that has a large Comorian and Afro-Caribbean community (Chiaroni et al, 2004). The presence of this large minority population poses a major transfusional challenge because of the high frequency of blood diseases such as SCD. To allow routine evaluation of alloimmunization risk, we have developed two simple and clinically useful genotyping assays based on the well-known SNaPshot method (Di Cristofaro et al, 2010; Silvy et al, 2011). One is a multiplex primer extension assay ( $\mathrm{SNaPshot}$ assay) allowing analysis of nucleotides at key positions 340, 667, 712, 733 and 1006 of the RHCE gene and position 1910 of the KEL gene designed to identify $c e^{s}(340)$, ceMO/AR/EK/BI/SM, $c e^{s}, c e^{s}(1006)$ and $K E L * 6 / * 7$ alleles. The other is a multiplex fragment assay allowing the detection of the presence of $R H D$, $R H D \psi$ and $R H C E^{*} C$ genes as well as $(C) c e^{s}$ Type 1 and DIII Type $5 c e^{s}$ haplotypes (Pham et al, 2009b; Poulter et al, 1996; Singleton et al, 2000).

The purpose of this report is to describe the results of a prospective study carried out after validation of the specificity and reliability of these two molecular assays. Study was carried out on two cohorts of African descent, i.e., 184 Comorians living in the south of France and 1021 Afro-Caribbean donors from Martinique Island. Our goal was to determine their RHCE and KEL polymorphisms and to have a better knowledge of the allelic frequencies to minimize production of $\mathrm{Rh}$ and Kell allo antibodies, to reduce complications and improve transfusion therapy. 


\section{Genomic DNA extraction}

Genomic DNA was extracted from $200 \mu \mathrm{l}$ of whole blood using the MagNA Pure LC DNA Isolation Kit (Roche, Meylan, France) according to the manufacturer's instructions. DNA was eluted in $100 \mu \mathrm{l}$ water and quantified by measuring optical density.

Detection of RHCE and KEL polymorphisms by multiplex PCR, primer extension assay, and capillary electrophoresis analysis

A multiplex PCR was developed to amplify RHCE-gene exons 3, 5 and 7 and exon 17 of $K E L$ gene (Table 2). Amplification was performed using a PTC200 thermocycler (Biorad, France) on $200 \mathrm{ng}$ of genomic DNA in a final volume of $25 \mu \mathrm{l}$ containing PCR Qiagen Master Mix, Q solution (Qiagen, Courtaboeuf, France), and primer sets (see Table 2 for final concentration). After an initial denaturation step at $95^{\circ} \mathrm{C}$ for 15 minutes, a total of 35 cycles were carried out 
using the following sequence: denaturation at $95^{\circ} \mathrm{C}$ for 30 seconds, primer annealing at $57^{\circ} \mathrm{C}$ for 90 seconds, and polymerization at $72^{\circ} \mathrm{C}$ for 90 seconds. Amplification was terminated after a 10 min-extension at $72^{\circ} \mathrm{C}$. Amplicons were controlled on $2 \%(\mathrm{wt} / \mathrm{vol})$ agarose gel. Purification of amplified products $(10 \mu \mathrm{l})$ were performed using 10 units of Exonuclease I and 3.3 units of shrimp alkaline phosphatase (Euromedex, Souffelweyersheim, France) for 60 minutes at $37^{\circ} \mathrm{C}$ followed by enzyme inactivation for 15 minutes at $80^{\circ} \mathrm{C}$. The next step consisted of single-base primer extension using the SNaPshot kit (Applied Biosystems, Courtaboeuf, France) according to the manufacturer's protocol. This reaction was carried out in a final volume of $10 \mu \mathrm{l}$ containing $3 \mu \mathrm{l}$ of purified PCR products, $5 \mu \mathrm{l}$ of SNaPshot ready reaction premix, and extension primers (see Table 2 for final concentration). The extension reaction included 25 cycles of denaturation at $96^{\circ} \mathrm{C}$ for 10 seconds, annealing at $50^{\circ} \mathrm{C}$ for 5 seconds, and extension at $60^{\circ} \mathrm{C}$ for 30 seconds. After treatment with shrimp alkaline phosphatase, $0.5 \mu \mathrm{l}$ of the $\mathrm{SNaPshot}$ primer extension reaction product was mixed with formamide and $120 \mathrm{LIZ}$ ladder before analysis on a capillary sequencer (ABI PRISM3130XL, Applied Biosystems) using POP 7 polymer according to the manufacturer's instructions. Data were analyzed using GeneMapper v4.0 software (Applied Biosystems). For each SNaPshot analysis, positive and negative controls were performed by replacing genomic DNA with already genotyped DNA and $\mathrm{H}_{2} \mathrm{O}$ (DNase/RNase free, Invitrogen) respectively.

\section{Multiplex PCR and capillary electrophoresis analysis}

A multiplex fragment assay was developed to detect the presence of RHD, RHD $\psi$ and $R H C E^{*} C$ genes and to reveal $455 \mathrm{~A}>\mathrm{C}$ transversion located in $R H D$ exon-3 consistent with (C) $c e^{s}$ Type 1 and DIII Type $5 c e^{s}$ haplotypes. Amplification of the CCR5 exon-2 was used as an internal control. Amplification was performed using a PTC 200 thermocycler (Biorad, France) on $200 \mathrm{ng}$ of genomic DNA in a final volume of $25 \mu \mathrm{l}$ containing PCR buffer, $3 \mathrm{mmol} / 1 \mathrm{MgCl}_{2}, 0.2 \mathrm{mmol} / \mathrm{l}$ of each dNTP, 1 unit of Taq DNA polymerase (Invitrogen, Cergy Pontoise, France), and primers (see Table 3 for final concentrations). Conditions for multiplex PCR were as follows: $95^{\circ} \mathrm{C}$ for 5 minutes followed by 40 cycles of $95^{\circ} \mathrm{C}$ for 30 seconds, $59^{\circ} \mathrm{C}$ for 45 seconds, $72^{\circ} \mathrm{C}$ for 2 minutes, and $72^{\circ} \mathrm{C}$ for 7 minutes. As in the previous test, $1.5 \mu \mathrm{l}$ of PCR reaction product was mixed with formamide and $500 \mathrm{LIZ}$ ladder before analysis on a capillary sequencer (ABI PRISM3130XL, Applied Biosystems) using software (GeneMapper v4.0, Applied Biosystems). In each experiment, positive and negative controls were performed with already genotyped DNA and $\mathrm{H}_{2} \mathrm{O}$ (DNase/RNase free, Invitrogen) respectively. 
Further gene analysis

To distinguish between partial DIII Type $5 c e^{s}$ and $(C) c e^{s}$ Type 1 consistent with a $455 \mathrm{~A}>\mathrm{C}$ transversion located in $R H D$ exon-3 revealed by multiplex fragment assay and to identify $D A R$ linked to $c e A R$ and $c e E K$ alleles, the previously reported $\mathrm{SNaPshot}$ assay (Silvy et al, 2011) for detection of weak $D$ and $D E L$ alleles was used to analyze $R H D$ positions 602, 667, 819 and 1025. To distinguish between $c e E K, c e B I$ and $c e S M$ alleles, revealed by the $712 \mathrm{~A}>\mathrm{G}$ transition on SNaPshot assay, and between $c e E K$, ceBI or ceSM in trans to a $c e^{s}$ allele and ceAR, revealed by $712 \mathrm{~A}>\mathrm{G}$ and $733 \mathrm{C}>\mathrm{G}$ nucleotide changes, RHCE exon-5 were amplified by PCR from genomic DNA using sense primer (5' -gcaacagagcaagagtcca-3', nt -310 to -292) and anti-sense primer (5'-actcccccagaaagcctttg-3', nt +222 to +202$)$. PCR products were then cloned into pGEM-T vector (Promega) and sequenced using a sequencing kit (BigDye Terminator v1.1, Applied Biosystems) and a genetic analyzer (ABI PRISM3130XL, Applied Biosystems) according to manufacturer's protocol. To distinguish between ceBI and ceSM alleles, RHCE exon-8 was amplified and sequenced to determine the nucleotide at position 1132. $R^{N}$ haplotype from samples typed DCCee was investigated to identify the RH:-46, RH32 phenotype, using TaqMan assay as previously described (Tournamille et al, 2010). 


\section{RESULTS}

Validation of assays

The first assay, i.e., multiplex PCR coupled with a single base extension reaction using genomic DNA, was designed for simultaneous determination of 6 SNPs defining 6 variant $R H C E^{*} \mathrm{ce}$ alleles and $K E L * 6 / * 7$ alleles observed in individuals of African descent. The primer sets selected to amplify RHCE exons 3, 5, 7 and KEL exon 17 are shown in table 2. For each PCR, the specificity of amplicons was evaluated in singleplex and multiplex reactions in which PCR conditions, DNA template, and primer concentrations were adjusted to obtain bands of similar intensity (data not shown). The entire assay including multiplex PCR, primer extension (see Table 2), electrophoresis, and fluorescent typing step was calibrated to obtain electrophoretic peaks of at least 500 rfus at regular intervals. Genomic DNA samples already genotyped for $R H C E^{*} c e$ variants and/or $K E L^{*} 6 / * 7$ were used to validate the SNaPshot signal at each assay position, i.e., 340, 667, 712, 733 and 1006 of the RHCE and 1910 of the KEL gene, The validation set included $c e^{s}$ (n=8, four homozygous samples), $(C) c e^{s}$ Type 1 ( $\mathrm{n}=10$, one homozygous sample), DIII Type $5 c e^{s}(\mathrm{n}=4$, one homozygous sample), $c e^{s}(340)(\mathrm{n}=1$, heterozygous form), $c e A R(\mathrm{n}=6$, all in trans to a $c e$ allele), $\operatorname{ceEK}(\mathrm{n}=1$, heterozygous form), and ceMO ( $\mathrm{n}=10$, one homozygous sample). Also included in the validation set were ten $K E L * 7 / * 7$, five $K E L * 6 / * 7$, and three $K E L * 6 / * 6$ samples.

The second genomic DNA assay, i.e., multiplex PCR using 8 primer sets each including one labeled primer (see Table 3), was designed for simultaneous amplification of wild type $R H D$ exon-3, $-4,-5$ and $-10, R H D$ exon-3 (455A $>C$ ), $R H D \Psi$ exon-4, $R H C E^{*} C$ intron-2, and CCR5 exon-2 as positive control. After optimization of singleplex and multiplex reaction conditions as described above, multiplex fragment signals were validated using a validation set composed of genomic DNA samples genotyped $R H D \Psi(\mathrm{n}=6$, one of them with $R H C E^{*} C$ allele), $(C) c e^{s}$ Type $1\left(\mathrm{n}=10\right.$, one with $R H C E^{*} C$ allele), $R H D$ deletion $(d e l / d e l, \mathrm{n}=$ 6, four of them with $R H C E^{*} C$ allele), and $R H D\left(\mathrm{n}=10\right.$, five with $R H C E^{*} C$ allele).

Results obtained with both assays were fully concordant with known RHDCE and KEL genotypes. Typical GeneMapper electropherograms obtained after capillary electrophoresis in a POP7 polymer system are presented in figure 1 showing the relevance of the two molecular analyses at polymorphic positions $340 \mathrm{C}>\mathrm{T}, 667 \mathrm{G}>\mathrm{T}, 712 \mathrm{~A}>\mathrm{G}, 733 \mathrm{C}>\mathrm{G}$ and $1006 \mathrm{G}>\mathrm{T}$ of the RHCE gene and 1910G $>\mathrm{T}$ of the KEL genes (panel A) and wild type $R H D$ exon-3, $-4,-5$ and $-10, R H D$ exon-3 (455A $>\mathrm{C}), R H D \Psi$ exon-4, $R H C E^{*} C$ intron-2 and CCR5 exon-2 as positive control (panel B). Electrophoregram interpretations are given in 


\section{Prospective study in two cohorts of African descent}

Prospective study starting with the SNapShot assay was carried out on a total of 184 Comorian and 1021 Afro-Caribbean donors RhDCE phenotyped with commercial MoAb reagents. In a second step, DNA samples presenting nucleotide changes at positions $733 \mathrm{C}>\mathrm{G}$ and $1006 \mathrm{G}>\mathrm{T}$ were investigated using the multiplex fragment assay to identify active and inactive $R H D$ molecular background, $R H C E^{*} C$ gene, and $455 \mathrm{~A}>\mathrm{C}$ transversion located in RHD exon-3 consistent with $(C) c e^{s}$ Type 1 and DIII Type $5 c e^{s}$ haplotypes.

Phenotype findings showed that 11 (5.97\%) Comorians and 92 (9.01\%) AfroCaribbeans were $\mathrm{RhD}$ negative. As expected, the RhDCe, DcE, Dce and dce phenotypes were the most frequent in both cohorts, resulting from $D C e\left(R_{1}\right), D c E\left(R_{2}\right), D c e\left(R_{0}\right)$ and $d c e(r)$ haplotypes that are the most frequent in Africans populations (data not shown). Genotype findings (based on screening of polymorphism positions 340, 667, 712, 733 and 1006 of RHCE gene and on $R H$ haplotype analysis) were all consistent with serologic results for RhDCE status and showed that 108 (58.69\%) Comorians and 421 (41.23\%) Afro-Caribbeans carried at least one variant $R H C E^{*} c e$ allele or $R H$ haplotype (see Table 5).

The most frequent variants were the classic $c e^{s}$ allele identified in $72(39.13 \%)$ Comorians and 330 (32.32\%) Afro-Caribbeans, $(C) c e^{s}$ Type 1 (14.67\% and 5.28\%, respectively) and DIII Type $5 c e^{s}$ haplotypes (4.88\% and 1.76\%, respectively). Variant $R H C E^{*} c e$ alleles or $R H$ haplotypes were found in compound heterozygosity with each other in only $16(8.69 \%)$ Comorians and 51 (4.99\%) Afro-Caribbeans.

Only 48 (26.08\%) Comorians and 150 (14.69\%) Afro-Caribbeans showed genotypes consistent with likely partial D, C, c and/or e antigen expression resulting from DARceAR, DIII Type $5 c e^{s}$, and $(C) c e^{s}$ Type 1 haplotypes and/or variant $R H C E^{*} c e$ alleles, in the absence of conventional $R H C E^{*} c e$ or $R H C E^{*} C e$ in trans.

No homozygous genotype corresponding to the absence of high-prevalence antigens, i.e., RH:-18, -34 and -46 phenotype, was found. Conversely, 116 (63\%) Comorians and 496 (48.60\%) Afro-Caribbeans expressed low-prevalence antigens resulting from variant $R H C E$ alleles and/or $K E L * 6$ allele. The most frequent alleles encoded VS, V and KEL6. KEL*6/*7 analysis revealed that $41(22.28 \%)$ Comorians and $158(15.47 \%)$ Afro-Caribbeans carried at 
least one $K E L^{*} 6$ allele. Two Comorian and 9 Afro-Caribbean samples were homozygous $K E L * 6 / * 6$ with the rare $\mathrm{Js}_{\mathrm{s}}(\mathrm{a}+\mathrm{b}-)$ phenotype.

A novel variant $R H C E^{*} c e$ allele was identified in one Afro-Caribbean sample with a RhCce phenotype. It was found to share the $733 \mathrm{C}>\mathrm{G}$ transversion in collinear association with the $712 \mathrm{~A}>\mathrm{G}$ transition in $R H C E$ exon-5, after sequencing of $10 R H C E$ exons. These two nucleotide changes are consistent with an $R H C E^{*} c e(238 \mathrm{Val}, 245 \mathrm{Val})$ allele named $R H C E^{*} c e^{s}$ (712). Testing to rule out high-prevalence antigens could not be performed due to the presence of conventional $R H C E^{*} C e$ in trans encoding a normal e antigen. Nevertheless, the likelihood of VS low-incidence antigen is great since VS expression requires Leu245Val in an RHCE protein encoded by the guanine at position 733 in RHCE exon 5.

\section{Experimental allele frequencies}

Based on these genotype results, the experimental frequencies of variant $R H C E^{*} c e$ alleles, $R H$ haplotypes, and $K E L * 6 / * 7$ alleles were calculated for each cohort. As shown in table 6, these gene features were consistently more frequent in Comorians than in AfroCaribbeans. The most frequent were the $c e^{s}$ allele that was found in $20.38 \%$ of Comorians versus $17.82 \%$ of Afro-Caribbeans, the $(C) c e^{s}$ Type 1 haplotype in $7.33 \%$ versus $2.64 \%$, and the DIII Type5 $c e^{s}$ haplotype in $2.44 \%$ versus $0.88 \%$. All other experimental allele frequencies were lower than one percent except for ceMO allele that was found $1.63 \%$ in Comorians. The frequency of $K E L * 6$ allele expressing low-prevalence antigen was $11.68 \%$ in Comorians versus $8.18 \%$ in Afro-Caribbeans. 


\section{DiSCUSSION}

Preventing alloimmunization is a daily concern in transfusion medicine particularly for patients with diseases such as SCD that require long-term transfusion therapy. Developing molecular tools for simultaneous detection of various alloimmunization risk factors including presence/absence of high- and low-prevalence antigens as well as expression of partial antigens remains a major challenge. All recent reports have underlined the value of extensive molecular typing of recipients and donors (Hillyer et al, 2008; Reid 2007; Westhoff 2008). For SCD patients, previous studies indicate that molecular typing can reduce labor and reagent costs and to enhance the benefit of transfusion therapy (Guelsin et al, 2010; Pham et al, 2011; Ribeiro et al, 2009).

The present study describes two genotyping assays. The first is a multiplex SNaPshot assay designed for simultaneous analysis of 6 key SNPs defining a spectrum of 6 variant $R H C E^{*} \mathrm{ce}$ alleles and $K E L^{*} 6 / * 7$ alleles. All targeted variant $R H C E^{*} c e$ alleles are considered in Noizat-Pirenne guidelines as prevalent or clinically relevant for molecular identification of $\mathrm{RhCE}$ phenotypes in individuals of African descent at risk for alloimmunization against lowand high-incidence antigens (Noizat-Pirenne et al, 2002). KEL6 (Js ${ }^{\mathrm{a}}$ ), which was first reported in 1958 (Giblett 1958), occurs in $20 \%$ of Afro-Americans versus less than $1 \%$ in the rest of the populations and has been implicated in immunogenic responses and fetal anemia. The second assay described here is a multiplex fragment assay allowing detection of $R H D$, $R H D \psi$ and $R H C E^{*} C$ genes as well as the $455 \mathrm{~A}>\mathrm{C}$ transversion consistent with $(C) c e^{s}$ Type 1 and DIII Type $5 c e^{s}$ haplotypes. Found exclusively in blacks, $(C) c e^{s}$ Type 1 encodes weak partial C, partial c, weak partial e, VS, and Rh42 (Daniels et al, 1998; Faas et al, 1997; Pham et al, 2009a). Since $(C) c e^{s}$ Type 1 does not produce $\mathrm{hr}^{\mathrm{B}}$ and $\mathrm{Hr}^{\mathrm{B}}$ high-prevalence antigens, it induces in the homozygous state, the rare RH:-34 phenotype with risk of transfusion deadlock (Noizat-Pirenne et al, 2002; Pham et al, 2011). DIII Type $5 c e^{s}$ is relevant to transfusion because it can lead to production of alloanti-D and alloanti-hr ${ }^{\mathrm{B}}$ and anti-Hr${ }^{\mathrm{B}}$ in the absence of conventional $R H C E^{*} c e$ or $C e$ in trans (Westhoff et al, 2010). In addition to these two genotyping assays, a TaqMan assay was used to identify $R^{N}$ homozygous consistent with the lack of expression of the RH46 high-prevalence antigen and the appearance of the RH32 low-incidence antigen (RH:32,-46 phenotype) (Le Pennec et al, 1989; Rouillac et al, 1996).

After validating the specificity and reliability of these two multiplex assays, a prospective study was conducted on two cohorts of unrelated donors including 184 Comorians from Grande Comore Island and 1021 Afro-Caribbeans from Martinique Island. 
These two cohorts of African descent present different rates of racial admixture and are representative of diversity in the general population in the two locations. As expected, our results showed a wide diversity of RHDCE and KEL genotypes in both Comorians and AfroCaribbeans. More than 50 different $R H$ genotypes were found, confirming the heterogeneous nature of $R H$ genes. Variant $R H C E$ alleles and $R H$ haplotypes expressing low-incidence antigens were usually present in heterozygote with another common RHCE allele. More than one out of two genotypes produced V, VS, JAL and/or KEL6 low-incidence antigens posing a risk for negative recipients. However, no homozygous $R^{N}$ and no ceSM alleles expressing RH32 and RH49(STEM) respectively were detected. A clear implication of these findings is that intra-ethnic blood transfusion does not rule out the need for extended matching to lower the risk of alloimmunization due to low-prevalence antigens.

Findings showed that $26.08 \%$ of Comorians and $14.69 \%$ of Afro-Caribbeans expressed partial D, C, c, and/or e antigens resulting from DAR, DIII Type $5 c e^{s}$ and $(C) c e^{s}$ haplotypes and/or variant $R H C E^{*} c e$ alleles. Assuming that the $c e^{s}$ allele has $48 \mathrm{C}$ (position not tested) and $733 \mathrm{G}$, it can be estimated that more than half, i.e., $14.67 \%$ and $8.81 \%$ respectively, do not expressed the $\mathrm{hr}^{\mathrm{B}}$ high-prevalence antigen. Half of these were $\mathrm{hr}^{\mathrm{B}}$ - and $\mathrm{E}$ negative, a valuable phenotype for SCD patients. Finding suitable blood for patients with anti-hr ${ }^{\mathrm{B}}$ can be problematic since anti-hr ${ }^{\mathrm{B}}$ antibodies produced by patients with different molecular background are not always compatible with all $\mathrm{hr}^{\mathrm{B}}$ - red cells (Reid et al, 1997; Vege \& Westhoff 2006). Only three donors heterozygous for ceMO or $c e A R$ in trans to a $R H C E^{*} c E$ allele correlated with the lack of the $\mathrm{hr}^{\mathrm{S}}$ high-prevalence antigen. Anti-hr ${ }^{\mathrm{S}}$ antibody is clinically relevant since it has been implicated in a number of transfusion fatalities (NoizatPirenne et al, 2002). Once again, anti-hr $\mathrm{S}^{\mathrm{S}}$ are not always compatible with all $\mathrm{hr}^{\mathrm{S}}$ - red cells since negative $\mathrm{hr}^{\mathrm{S}}$ phenotypes may be encoded by different $R H C E^{*} c e$ alleles (ceMO/AR/EK/BI/SM) (Noizat-Pirenne et al, 2002; Noizat-Pirenne et al, 2001). Two Comorians and 9 Afro-Caribbeans displayed a complex difficult-to-predict mosaic-type that resulted from variant $R H C E^{*} c e$ alleles and $R H$ haplotypes present in compound heterozygosity with each other. To further complicate matters, the partial $\mathrm{RhD}$ phenotype occurred in 6 Afro-Caribbeans genotyped dce/DIII Type $5 c e^{s}(\mathrm{n}=5)$ or RHDWce/DARceAR, $(\mathrm{n}=1)$ though it must be stressed that the DIVaceTI and DIII Type 5 ceTI haplotypes were not investigated (Hemker et al, 1999; Westhoff et al, 2010). These findings again underline the need for donor/recipient RH matching, which can only be achieved by DNA analysis, to prevent alloimmunization. 
Evidence that $c e^{s}, c e^{s}(340), c e M O, c e A R / B I / E K,(C) c e^{s}$ Type 1, DIII Type $5 c e^{s}$ and $c e^{s}(1006)$ may induce potentially immunogenic partial phenotypes and/or expression of lowprevalence antigens in Afro-Caribbeans and Comorians led us to evaluate the experimental frequency of these alleles. The incidence of rare phenotypes in the Afro-Caribbean was deduced from the frequency of the alleles at homozygous state: RH:-31 [ce $\left.e^{s}\right]: 1 / 31$; Js (a+b-) [KEL*6]: 1/149; RH:-34 [(C)ce Type 1, DIII Type $\left.5 c e^{s}, c e^{s}(1006)\right]: 1 / 742 ; \mathrm{RH}:-18$ [ceAR/BI/EK]: 1/13,211; RH:-19 [ceMO]: 1/24,414 and RH:-57 [ce $(340)]: 1 / 4 \times 10^{6}$ (see Tables 1 and 6). In the Comorian cohort, the incidence of the corresponding phenotypes was RH:-31: 1/24; Js (a+b-): 1/73; RH:-34: 1/99; RH:-18: 1/5,486; RH:-19: 1/3,763 and RH:-57: 1/137,000. Having a rate of racial admixture lower than Afro-Caribbeans, Comorians logically showed higher frequencies of rare phenotypes. No homozygous $R^{N}$ genotype was found in either cohort. These frequency data clearly indicate priority targets which must be first investigated in donors and patients to optimize use of compatible units and improve transfusion. However, the cost of molecular investigations remains limiting factor.

To our knowledge, this is the first report describing molecular identification of RHCE and KEL variants in large representative cohorts of donors of African descent, at high level of complexity to determine the allele frequencies. Findings showed a wide diversity of genotypes with a significant percentage of donors negative for high-prevalence and partial RhDCE antigens, and donors positive for low prevalence Rh and Kell antigens. Experimental allele frequency data clearly indicated that intra-ethnic blood transfusion alone cannot prevent alloimmunization. Similarly, extended $\mathrm{Rh}$ antigen phenotyping cannot fully evaluate the alloimmunization risk since it may not distinguish variant $\mathrm{Rh}$ antigens from conventional antigens. Indeed phenotyping reveals only altered expression of conventional antigens but then DNA analysis must be performed for reliable RhCE variant typing.

This study confirms the potential benefit of RH genotyping as a complement to serologic phenotyping. Knowledge about donor genotype is essential to assessing the potential risk of alloimmunization and could allow selection of compatible blood units especially for genotyped SCD patients with antibodies to high-prevalence antigens. An additional benefit of the molecular assays in transfusion practice would be to provide molecularly defined control RBCs for antibody identification.

The two multiplex assays described here and TaqMan assay for $R^{N}$ homozygosity have been implemented into routine in our regional pretransfusion laboratory. We now perform more than 300 genotypes per year. Each genotyping can be obtained in 1.5 working days including hand-on time of 6 hours and machine-on time of 8 hours. Unit cost for one DNA extraction 
and one multiplex assay including personnel, instrument-time, and consumable costs are estimated at $\$ 37.8$. When sequencing analyses are needed, two extra days are required for the final genotype. Use of assays is currently restricted to patients of African descent presenting atypical profiles with anti-Rh MoAbs and SCD patients, to take into account the variant alleles in the research of matched RBC units. Since some phenotypes may be encoded by different alleles, a high level of complexity is required to avoid alloimmunization (Reid et al, 1997; Noizat-Pirenne et al, 2002; Vege \& Westhoff 2006). It will soon be extended to African donors for selection of rare blood units for SCD patients. Further study funded by the Établissement Français du Sang is under way to identify the Rh variants that may alter the Rh antigenic complex to become immunogenic with production of clinically significant antibodies.

Acknowledgments: We wish to thank the staff of haematology laboratories of EFS AlpesMéditerranée for providing blood samples used in this study. We also thank Andrew Corsini for proofreading the manuscript. M. Silvy developed the assays, analysed the data and wrote the paper, J. Di Cristofaro developed and performed the SNaPshot assays, S. Beley performed the other assays, K. Papa, M. Rits and P. Richard contributed essential blood samples, J. Chiaroni contributed to design the research and P. Bailly designed the research, analysed the data and wrote the paper. The authors declare that they have no conflict of interest in the subject matter of their article. 


\section{REFERENCES}

Avent, N.D. \& Reid, M.E. (2000) The Rh blood group system: a review. Blood, 95, 375-387.

Aygun, B., Padmanabhan, S., Paley, C. \& Chandrasekaran, V. (2002) Clinical significance of RBC alloantibodies and autoantibodies in sickle cell patients who received transfusions. Transfusion, 42, 37-43.

Chiaroni, J., Touinssi, M., Frassati, C., Degioanni, A., Gibert, M., Reviron, D., Mercier, P. \& Boetsch, G. (2004) Genetic characterization of the population of Grande Comore Island (Njazidja) according to major blood groups. Hum Biol, 76, 527-541.

Chou, S.T. \& Westhoff, C.M. (2009) Molecular biology of the Rh system: clinical considerations for transfusion in sickle cell disease. Hematology Am Soc Hematol Educ Program, 178-184.

Daniels, G. (2002) Human blood groups. Oxford: Blackwell Science.

Daniels, G.L., Faas, B.H., Green, C.A., Smart, E., Maaskant-van Wijk, P.A., Avent, N.D., Zondervan, H.A., von dem Borne, A.E. \& van der Schoot, C.E. (1998) The VS and V blood group polymorphisms in Africans: a serologic and molecular analysis. Transfusion, 38, 951-958.

Di Cristofaro, J., Silvy, M., Chiaroni, J. \& Bailly, P. (2010) Single PCR multiplex SNaPshot reaction for detection of eleven blood group nucleotide polymorphisms: optimization, validation, and one year of routine clinical use. J Mol Diagn, 12, 453-460.

Faas, B.H., Beckers, E.A., Wildoer, P., Ligthart, P.C., Overbeeke, M.A., Zondervan, H.A., von dem Borne, A.E. \& van der Schoot, C.E. (1997) Molecular background of VS and weak C expression in blacks. Transfusion, 37, 38-44.

Flickinger, C. (2006) In search of red blood cells for alloimmunized patients with sickle cell disease. Immunohematology, 22, 136-142.

Giblett, E.R. (1958) Js, a new blood group antigen found in Negroes. Nature, 181, 1221-1222.

Guelsin, G.A., Sell, A.M., Castilho, L., Masaki, V.L., Melo, F.C., Hashimoto, M.N., Higa, T.T., Hirle, L.S. \& Visentainer, J.E. (2010) Benefits of blood group genotyping in multitransfused patients from the south of Brazil. J Clin Lab Anal, 24, 311-316.

Halter-Hipsky, C., Hue-Roye, K., Coghlan, G., Lomas-Francis, C. \& Reid, M.E. (2009) Two alleles with RHCE*nt818C $>$ T change encode the low prevalence Rh antigen STEM. Blood, 114, Abstract 3159.

Hemker, M.B., Ligthart, P.C., Berger, L., van Rhenen, D.J., van der Schoot, C.E. \& Wijk, P.A. (1999) DAR, a new RhD variant involving exons 4, 5, and 7, often in linkage with ceAR, a new Rhce variant frequently found in African blacks. Blood, 94, 4337-4342.

Higgins, J.M. \& Sloan, S.R. (2008) Stochastic modeling of human RBC alloimmunization: evidence for a distinct population of immunologic responders. Blood, 112, 2546-2553.

Hillyer, C.D., Shaz, B.H., Winkler, A.M. \& Reid, M. (2008) Integrating molecular technologies for red blood cell typing and compatibility testing into blood centers and transfusion services. Transfus Med Rev, 22, 117-132.

Huang, C.H., Johe, K., Moulds, J.J., Siebert, P.D., Fukuda, M. \& Blumenfeld, O.O. (1987) Delta glycophorin (glycophorin B) gene deletion in two individuals homozygous for the S-s--U-- blood group phenotype. Blood, 70, 1830-1835.

Isaak, E.J., LeChien, B., Lindsey, T. \& Debaun, M.R. (2006) The Charles Drew program in Missouri: a description of a partnership among a blood center and several hospitals to address the care of patients with sickle cell disease. Immunohematology, 22, 112-116.

Le Pennec, P.Y., Rouger, P., Klein, M.T., Kornprobst, M., Brossard, Y., Boizard, B. \& Salmon, C. (1989) A serologic study of red cells and sera from 18 Rh:32,-46 (RN/RN) persons. Transfusion, 29, 798-802.

Lee, S. (1997) Molecular basis of Kell blood group phenotypes. Vox Sang, 73, 1-11. 
Lomas-Francis, C., Alcantara, D., Westhoff, C., Uehlinger, J., Valvasori, M., Castilho, L. \& Reid, M.E. (2009) JAL (RH48) blood group antigen: serologic observations. Transfusion, 49, 719-724.

Noizat-Pirenne, F. (2003) [Immunohematologic characteristics in the Afro-caribbean population. Consequences for transfusion safety]. Transfus Clin Biol, 10, 185-191.

Noizat-Pirenne, F., Lee, K., Pennec, P.Y., Simon, P., Kazup, P., Bachir, D., Rouzaud, A.M., Roussel, M., Juszczak, G., Menanteau, C., Rouger, P., Kotb, R., Cartron, J.P. \& AnsartPirenne, H. (2002) Rare RHCE phenotypes in black individuals of Afro-Caribbean origin: identification and transfusion safety. Blood, 100, 4223-4231.

Noizat-Pirenne, F., Mouro, I., Le Pennec, P.Y., Ansart-Pirenne, H., Juszczak, G., Patereau, C., Verdier, M., Babinet, J., Roussel, M., Rouger, P. \& Cartron, J.P. (2001) Two new alleles of the RHCE gene in Black individuals: the RHce allele ceMO and the RHcE allele cEMI. $\mathrm{Br}$ J Haematol, 113, 672-679.

Ong, J., Walker, P.S., Schmulbach, E., Storry, J.R., Vege, S., Westhoff, C., Lomas-Francis, C. \& Reid, M.E. (2009) Alloanti-c in a c-positive, JAL-positive patient. Vox Sang, 96, 240240.

Peyrard, T., Pham, B.N., Poupel, S., Martin-Blanc, S., Auxerre, C., Kappler-Gratias, S., Bonin, P., Rouger, P. \& Le Pennec, P.Y. (2009) Alloanti-c/ce in a c+ceAR/Ce patient suggests that the rare RHCE ceAR allele (ceAR) encodes a partial c antigen. Transfusion, 49, 2406-2411.

Pham, B.N., Peyrard, T., Juszczak, G., Auxerre, C., Godin, S., Bonin, P., Rouger, P. \& Le Pennec, P.Y. (2009a) Alloanti-c (RH4) revealing that the (C)ce s haplotype encodes a partial c antigen. Transfusion, 49, 1329-1334.

Pham, B.N., Peyrard, T., Juszczak, G., Beolet, M., Deram, G., Martin-Blanc, S., Dubeaux, I., Roussel, M., Kappler-Gratias, S., Gien, D., Poupel, S., Rouger, P. \& Le Pennec, P.Y. (2011) Analysis of RhCE variants among 806 individuals in France: considerations for transfusion safety, with emphasis on patients with sickle cell disease. Transfusion, DOI: 10.1111/j.1537-2995.2010.02970.x.

Pham, B.N., Peyrard, T., Juszczak, G., Dubeaux, I., Gien, D., Blancher, A., Cartron, J.P., Rouger, P. \& Le Pennec, P.Y. (2009b) Heterogeneous molecular background of the weak C, VS+, hr B-, Hr B- phenotype in black persons. Transfusion, 49, 495-504.

Poulter, M., Kemp, T.J. \& Carritt, B. (1996) DNA-based rhesus typing: simultaneous determination of RHC and RHD status using the polymerase chain reaction. Vox Sang, 70, 164-168.

Reid, M.E. (2007) Overview of molecular methods in immunohematology. Transfusion, 47, 10S-16S.

Reid, M.E., Storry, J.R., Issitt, P.D., Combs, M.R., Beal, C.L., Mallory, D.A. \& Blancher, A. (1997) Rh haplotypes that make e but not hrB usually make VS. Vox Sang, 72, 41-44.

Ribeiro, K.R., Guarnieri, M.H., da Costa, D.C., Costa, F.F., Pellegrino, J., Jr. \& Castilho, L. (2009) DNA array analysis for red blood cell antigens facilitates the transfusion support with antigen-matched blood in patients with sickle cell disease. Vox Sang, 97, 147-152.

Rouillac, C., Gane, P., Cartron, J., Le Pennec, P.Y., Cartron, J.P. \& Colin, Y. (1996) Molecular basis of the altered antigenic expression of $\mathrm{RhD}$ in weak $\mathrm{D}(\mathrm{Du})$ and $\mathrm{RhC} / \mathrm{e}$ in RN phenotypes. Blood, 87, 4853-4861.

Silvy, M., Simon, S., Gouvitsos, J., Cristofaro, J.D., Ferrera, V., Chiaroni, J. \& Bailly, P. (2011) Weak D and DEL alleles detected by routine SNaPshot genotyping: identification of four novel RHD alleles. Transfusion, DOI: 10.1111/j.1537-2995.2010.02830.x.

Singleton, B.K., Green, C.A., Avent, N.D., Martin, P.G., Smart, E., Daka, A., Narter-Olaga, E.G., Hawthorne, L.M. \& Daniels, G. (2000) The presence of an RHD pseudogene 
containing a 37 base pair duplication and a nonsense mutation in africans with the Rh Dnegative blood group phenotype. Blood, 95, 12-18.

Sosler, S.D., Jilly, B.J., Saporito, C. \& Koshy, M. (1993) A simple, practical model for reducing alloimmunization in patients with sickle cell disease. Am J Hematol, 43, 103-106.

Storry, J.R., Reid, M.E., Fetics, S. \& Huang, C.H. (2003) Mutations in GYPB exon 5 drive the S-s-U+(var) phenotype in persons of African descent: implications for transfusion. Transfusion, 43, 1738-1747.

Tahhan, H.R., Holbrook, C.T., Braddy, L.R., Brewer, L.D. \& Christie, J.D. (1994) Antigenmatched donor blood in the transfusion management of patients with sickle cell disease. Transfusion, 34, 562-569.

Tournamille, C., Meunier-Costes, N., Costes, B., Martret, J., Barrault, A., Gauthier, P., Galacteros, F., Nzouekou, R., Bierling, P. \& Noizat-Pirenne, F. (2010) Partial C antigen in sickle cell disease patients: clinical relevance and prevention of alloimmunization. Transfusion, 50, 13-19.

Vege, S. \& Westhoff, C.M. (2006) Molecular characterization of GYPB and RH in donors in the American Rare Donor Program. Immunohematology, 22, 143-147.

Vichinsky, E.P., Luban, N.L., Wright, E., Olivieri, N., Driscoll, C., Pegelow, C.H. \& Adams, R.J. (2001) Prospective RBC phenotype matching in a stroke-prevention trial in sickle cell anemia: a multicenter transfusion trial. Transfusion, 41, 1086-1092.

Wayne, A.S., Kevy, S.V. \& Nathan, D.G. (1993) Transfusion management of sickle cell disease. Blood, 81, 1109-1123.

Westhoff, C.M. (2008) 2007 Rock Oyen Symposium: The potential of blood group genotyping for transfusion medecine practice. Immunohematology, 24, 190-195.

Westhoff, C.M., Vege, S., Halter-Hipsky, C., Whorley, T., Hue-Roye, K., Lomas-Francis, C. $\&$ Reid, M.E. (2010) DIIIa and DIII Type 5 are encoded by the same allele and are associated with altered RHCE*ce alleles: clinical implications. Transfusion, 50, 13031311. 


\section{FigURES LEGENDS}

Fig. 1. GeneMapper electropherograms obtained from multiplex SNaPshot and fragment assays. Plots showing size (nt) versus relative fluorescence units (rfus) for two sets of genomic DNA samples and negative controls. (A) Electropherograms of SNaPshot assays showing wild type nucleotides at positions 340, 667, 712733 and 1006 obtained in a RHDce/ce, $K E L * 7 / * 7$ DNA sample (top) and C/G, G/T, T/C heterozygous at positions 733, 1006 and 1910 obtained in a $R H D c e /(C) c e^{s}$ Type $1, K E L * 6 / * 7$ DNA sample, (B) Electropherograms of multiplex fragment assays showing $R H D C e / c e$ and $R H D \Psi c e /(C) \mathrm{ce}^{\mathrm{s}}$ Type 1 genotypes. Nucleotide changes are indicated at SNP site. Stars indicate use of extension primer with reverse orientation. All plots were collected using POP-7 polymer under the conditions described in M\&M. Nucleotide positions tested are indicated across the top of the figure. 
Table 1. Specific alleles or haplotypes of the RHD, CE and KEL genes for absence of high-prevalence antigens and expression of altered or low-prevalence antigens

\begin{tabular}{|c|c|c|c|c|}
\hline $\begin{array}{l}\text { RH allele or } \\
\text { haplotype }\end{array}$ & $\begin{array}{c}\text { Absence of } \\
\text { high-prevalence } \\
\text { antigen }\end{array}$ & $\begin{array}{l}\text { Expression } \\
\text { of altered } \\
\text { antigen } \\
\end{array}$ & $\begin{array}{l}\text { Expression of } \\
\text { low-prevalence } \\
\text { antigen } \\
\end{array}$ & Reference \\
\hline$c e^{S}$ & RH31 $\left(h^{B}\right)$ & e & $\mathrm{RH} 10(\mathrm{~V}), \mathrm{RH} 20(\mathrm{VS})$ & Daniels et al. 1998 \\
\hline$c e A R$ & $\mathrm{RH} 18\left(\mathrm{Hr}^{\mathrm{S}}\right)$ & $c, e$ & $\mathrm{RH} 10(\mathrm{~V})$ & Noizat-Pirenne et al. 2002 \\
\hline ceEK & RH19 (hrs), & e & - & Peyrard et al. 2009 \\
\hline ceBl & & e & RH49(STEM) & Halter-Hipsky et al. 2009 \\
\hline ceSM & $\mathrm{RH} 19\left(\mathrm{hr}^{\mathrm{S}}\right)$ & e & RH49(STEM) & Halter-Hipsky et al. 2009 \\
\hline сеMO & $\mathrm{RH} 19\left(\mathrm{hr}^{\mathrm{S}}\right)$ & e & - & Noizat-Pirenne et al. 2001 \\
\hline$c e^{s}(340)$ & RH57 (CEST) & $c, e$ & $\begin{array}{l}\mathrm{RH} 10(\mathrm{~V}), \mathrm{RH} 20(\mathrm{VS}) \\
\mathrm{RH} 48(\mathrm{JAL})\end{array}$ & $\begin{array}{l}\text { Lomas-Francis et al. } 2009 \\
\text { Ong et al. } 2009\end{array}$ \\
\hline $\begin{array}{l}(C) c e^{s} \\
\text { DIII Type } 5 c e^{s} \\
c e^{s}(1006)\end{array}$ & $\begin{array}{l}\text { RH31 }\left(\mathrm{hr}^{\mathrm{B}}\right), \\
\text { RH34 }\left(\mathrm{Hr}^{\mathrm{B}}\right)\end{array}$ & $\begin{array}{l}\text { C, c, e } \\
\text { D, e } \\
\text { e }\end{array}$ & $\mathrm{RH} 20$ (VS) & $\begin{array}{l}\text { Daniels et al. } 1998 \\
\text { Noizat-Pirenne et al. } 2002 \\
\text { Pham et al. 2009a } \\
\text { Pham et al. 2009b } \\
\text { Tournamille et al. } 2010 \\
\text { Westhoff et al. } 2010\end{array}$ \\
\hline$R^{N}$ & $\mathrm{RH} 46$ (Sec) & $\mathrm{C}, \mathrm{e}$ & $\mathrm{RH} 32$ & $\begin{array}{l}\text { Le Pennec et al. } 1989 \\
\text { Rouillac et al.1996 } \\
\text { Tournamille et al. } 2010\end{array}$ \\
\hline$D A R$ & - & D & - & Hemker et al. 1999 \\
\hline KEL6 & $\mathrm{KEL7}\left(\mathrm{Js}^{\mathrm{b}}\right)$ & - & $\operatorname{KEL6}\left(\mathrm{Js}^{\mathrm{a}}\right)$ & Lee et al. 1997 \\
\hline delGYPB & MNS5 (U) & - & 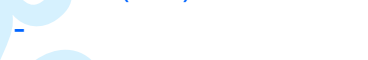 & Huang et al. 1987 \\
\hline $\begin{array}{l}\text { GYPB } B^{S}-I n t 5, \\
\text { GYPB }^{S}-230\end{array}$ & MNS3 (S) & $U^{\text {var }}$ & - & Storry et al. 2003 \\
\hline
\end{tabular}


Table 2. Primer sequences used for multiplex PCR amplification of $R H C E$ and $K E L$ exons and multiplex SNaPshot detection of 6 SNPs

\begin{tabular}{|c|c|c|c|c|c|c|}
\hline Gene exon & Direction & $5 ’ 3$ ' Primer sequence & $\begin{array}{c}\text { PCR } \\
\text { product } \\
\text { size (bp) } \\
\end{array}$ & $\begin{array}{c}\text { Primer } \\
\text { extension } \\
\text { size }(b p) \\
\end{array}$ & $\begin{array}{l}\text { SNP } \\
\text { site }\end{array}$ & $\begin{array}{c}\text { Final } \\
\text { concentration } \\
(\mathrm{nmol} / \mathrm{l})\end{array}$ \\
\hline \multirow[t]{3}{*}{ RHCE exon-3 } & Forward & TCTTCTATTTCCACAGAAAGTAA & \multirow{3}{*}{301} & & & 800 \\
\hline & Reverse & AGGTCCCTCCTCCAGCAC & & & & 800 \\
\hline & Forward & ${ }^{*} \mathrm{~T}_{(11)}$-CCTTCTCACCCCCAGTATT & & 30 & 340 & 440 \\
\hline \multirow{5}{*}{ RHCE exon-5 } & Forward & GGGCAACAGAGCAAGAGTCC & \multirow{5}{*}{483} & & & 600 \\
\hline & Reverse & TCACCATGCTGATCTTCCT & & & & 1200 \\
\hline & Forward & ${ }^{*} \mathrm{~T}_{(28)}$-GGATGTTCTGGCCAAGT & & 48 & 667 & 320 \\
\hline & Forward & ${ }^{*} \mathrm{~T}_{(35)}$-AATCCAAAGGAAGAATGCC & & 54 & 712 & 520 \\
\hline & Reverse & ${ }^{*} \mathrm{~T}_{(41)}$-GTCACCACACTGACTGCTA & & 60 & 733 & 140 \\
\hline \multirow{3}{*}{ RHCE exon-7 } & Forward & GGGGATTCACCACATCTCCG & \multirow{3}{*}{120} & & & 800 \\
\hline & Reverse & ACCCACATGCCATTGCCGTTC & & & & 800 \\
\hline & Reverse & ${ }^{*} \mathrm{~T}_{(46)}$-GGTGATCTCTCCAAGCAGAC & & 66 & 1006 & 80 \\
\hline \multirow{3}{*}{$K E L$ exon -17} & Forward & GTACCACCCACATCCTCACC & \multirow{3}{*}{167} & & & 1000 \\
\hline & Reverse & ATGGAAAGGCAGCATAATGG & & & & 1000 \\
\hline & Reverse & ${ }^{*} T_{(55)}$-CATGGTTGTCACAGGCG & & 72 & 1910 & 136 \\
\hline
\end{tabular}

All primers were tested for potential hairpin structures and primer-dimer problems on Integrated DNA Technologies website (http://eu.idtdna.com/analyzer/ applications/oligoanalyzer, version: 3.0, 2008). ${ }^{*}$ Each extension primer was designed to anneal immediately adjacent to the nucleotide at the SNP site on either the sense or anti-sense DNA strand. Their lengths differ by addition to the 5'-end of a polyT tail so that they can be distinguished by capillary electrophoresis. All extension primers were synthesized by Eurogentec (Seraing, Belgium) and purified by HPLC to remove incomplete primer synthesis products. 
Table 3. Primer sequence used for multiplex amplification of $R H D$ silent genes and $R H C E{ }^{\star} C$ allele

\begin{tabular}{|c|c|c|c|c|}
\hline Gene exon & Direction & $5 ’ 3$ 'PCR-primer sequence & $\begin{array}{l}\text { Final concentration } \\
(\mathrm{nmol} / \mathrm{l})\end{array}$ & $\begin{array}{l}\text { PCR product } \\
\text { size (bp) }\end{array}$ \\
\hline \multirow{2}{*}{$R H D$ exon-3 } & Forward & TCGGTGCTGATCTCAGTGGA & 1000 & \multirow{2}{*}{110} \\
\hline & Reverse & 6-FAM-ACTGATGACCATCCTCAGGG & 800 & \\
\hline \multirow{2}{*}{$\begin{array}{c}R H D \text { exon-3 } \\
\quad(455 A>C)\end{array}$} & Forward & TCGGTGCTGATCTCAGTGGA & 1000 & \multirow{2}{*}{110} \\
\hline & Reverse & PET-ACTGATGACCATCCTCAGGT & 1300 & \\
\hline \multirow{2}{*}{$R H D$ exon-4 } & Forward & NED- ATGGCAGACAAACTGGGTGTC & 2200 & \multirow[b]{2}{*}{71} \\
\hline & Reverse & CTGCCAAAGCCTCTACACG & 2200 & \\
\hline \multirow{2}{*}{$\begin{array}{l}R H D \Psi \text { exon-4 } \\
\text { (37 bp duplication) }\end{array}$} & Forward & NED-AACCTGGGAGGCAAATGTT & 8000 & \multirow{2}{*}{250} \\
\hline & Reverse & AATAAAACCCAGTAAGTTCATGTGG & 8000 & \\
\hline \multirow{2}{*}{$R H D$ exon-5 } & Forward & VIC-CGCCCTCTTCTTGTGGATG & 70 & \multirow{2}{*}{82} \\
\hline & Reverse & GAACACGGCATTCTTCCTTTC & 70 & \\
\hline \multirow{2}{*}{$R H D$ exon-10 } & Forward & VIC-GGATTTTAAGCAAAAGCATCCAAGAA & 7600 & \multirow{2}{*}{291} \\
\hline & Reverse & ACTGGATGACCACCATCATAT & 7600 & \\
\hline \multirow{2}{*}{$\begin{array}{l}R H C E^{*} C \text { intron-2 } \\
\text { (109 bp insertion) }\end{array}$} & Forward & 6-FAM-CAGGGCCACCACCATTTGAAA & 3000 & \multirow{2}{*}{151} \\
\hline & Reverse & TGGTAGCAGGCGTCTGTAAAAAAA & 3000 & \\
\hline \multirow{2}{*}{ CCR5 exon-2 } & Forward & NED-ACCTGCTCAACCTGGCCAT & 200 & \multirow{2}{*}{90} \\
\hline & Reverse & TTCCAAAGTCCCACTGGGC & 200 & \\
\hline
\end{tabular}

All primers were tested for potential hairpin structures and primer-dimer problems on Integrated DNA Technologies website (http://eu.idtdna.com/analyzer/ applications/oligoanalyzer, version: 3.0, 2008). 
Table 4. Model for identification of variant $R H C E$ and $K E L$ alleles from multiplex SNaPshot and fragment assays

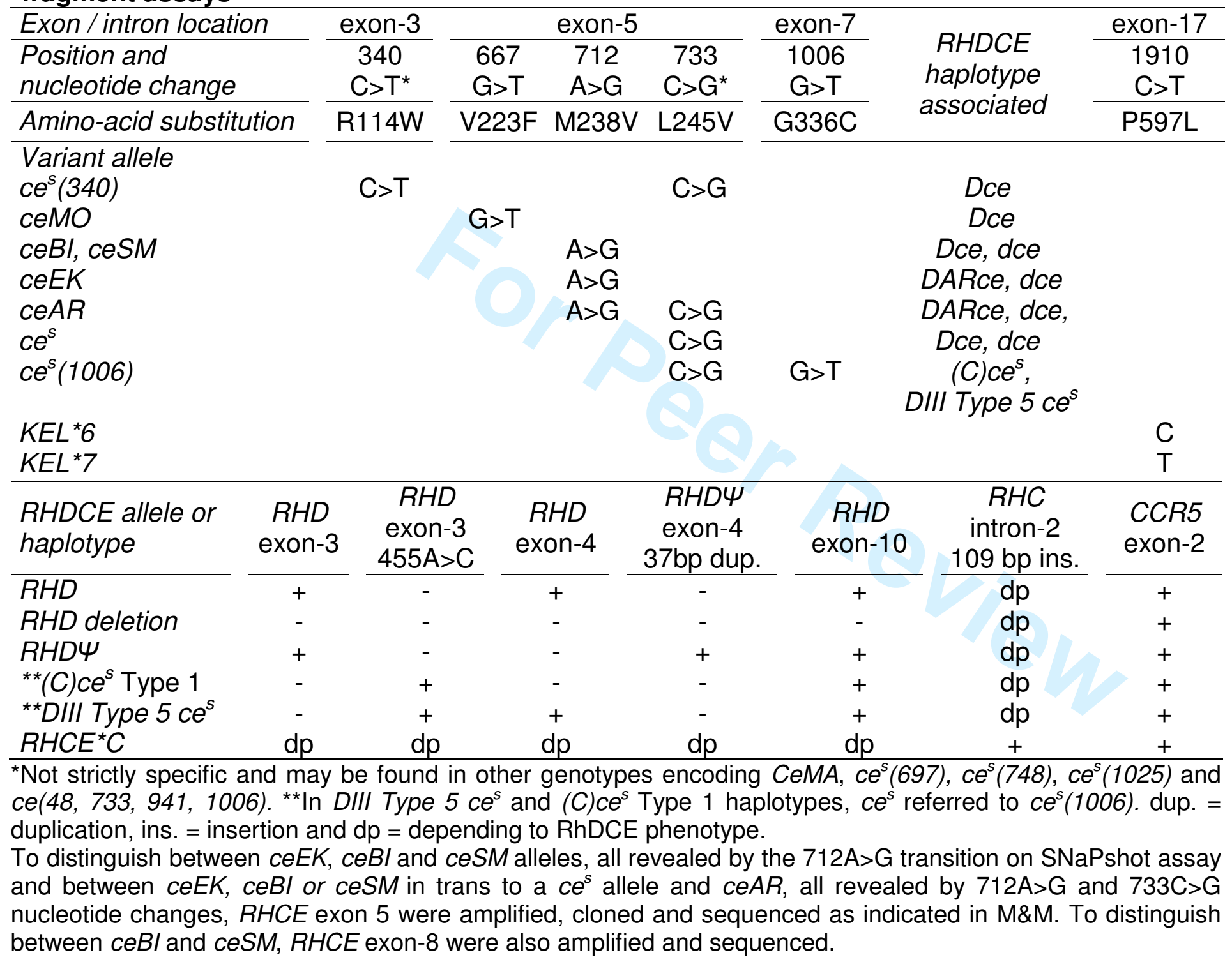


Table 5. RHCE and KEL genotypes observed in Afro-Caribbean and Comorian donors

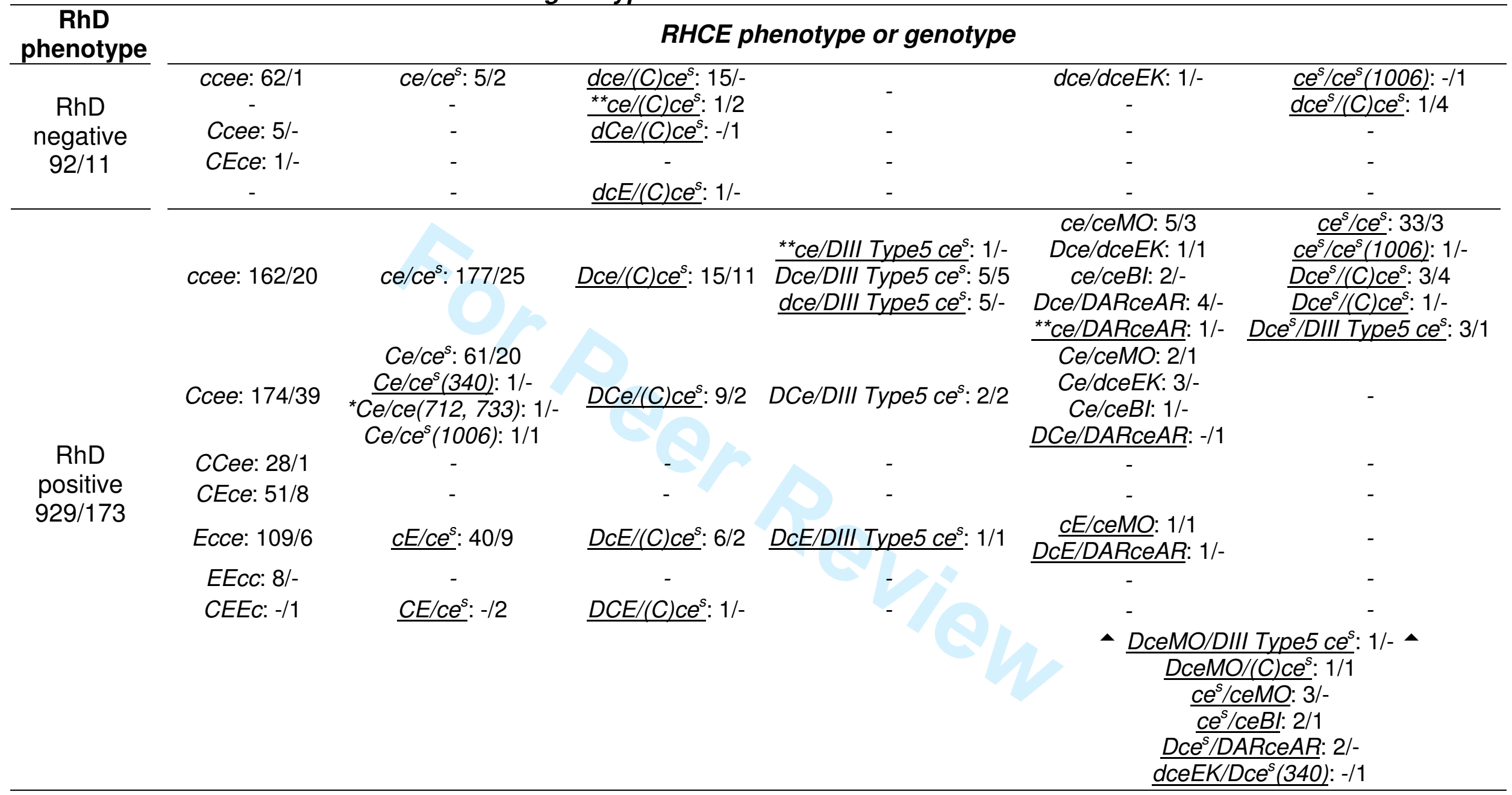

\section{KEL genotype} $K E L^{*} 7 /{ }^{*} 7: 863 / 143 \quad K E L{ }^{*} 6 /{ }^{*} 7: 149 / 39$ $K E L{ }^{*} 6 /{ }^{*} 6: 9 / 2$

Number of Afro-Caribbean donors (first number) and number of Comorian donors (second number). Underlined genotypes were consistent with likely partial D, C, c, and/or e antigen expressions. For samples with DIII Type $5 c e^{s},(C) c e^{s}$ Type 1 designated (C)ces in this table, DARceAR or $D A R c e E K$ haplotypes, the RHD genotype in trans were mentioned according to the RhD phenotype, fragment assay and the weak $\mathrm{D}$ and $\mathrm{DEL}$ SNaPshot assay. Variant $c e^{s}$ allele does not exclude $c e^{s}(697), c e^{s}(748), c e^{s}(1025)$ and $c e(48,733,941,1006)$ alleles. In DIII Type $5 c e^{s}$ and (C)ce haplotypes, $c e^{s}$ referred to $c e^{s}(1006)$.

${ }^{*}$ Variant $R h C E^{*} \mathrm{Ce}(712 \mathrm{G}, 733 \mathrm{G})$ allele not previously reported. $d=$ deletion of $R H D$ gene.

** genotype including a $R H D \Psi$ allele in trans. 
Table 6. Frequencies of variant RHCE and KEL alleles in AfroCaribbean and Comorian donors

\begin{tabular}{|c|c|c|c|}
\hline \multirow{2}{*}{$\begin{array}{c}\text { Allele } \\
\text { or haplotype }\end{array}$} & \multicolumn{2}{|c|}{ Experimental frequency } & \multirow[t]{2}{*}{$\begin{array}{c}\text { Expression of low } \\
\text { prevalence antigens }\end{array}$} \\
\hline & $\begin{array}{c}\text { Afro-Caribbean } \\
(n=1021)\end{array}$ & $\begin{array}{c}\text { Comorian } \\
(\mathrm{n}=184)\end{array}$ & \\
\hline$c e^{S}$ & 17.82 & 20.38 & $\mathrm{RH}: 10,20$ \\
\hline (C)ce $e^{s}$ Type 1 & 2.64 & 7.33 & $\mathrm{RH}: 20$ \\
\hline DIII Type $5 c e^{s}$ & 0.88 & 2.44 & $\mathrm{RH}: 20,48$ \\
\hline$c e^{s}(340)$ & 0.05 & 0.27 & $\mathrm{RH}: 10,20$ \\
\hline${ }^{*} c e^{s}(712)$ & 0.05 & - & $\mathrm{nt}$ \\
\hline$c e^{s}(1006)$ & 0.15 & 0.27 & $\mathrm{RH}: 20$ \\
\hline ceMO & 0.64 & 1.63 & \\
\hline$D A R c e A R$ & 0.39 & 0.54 & $\mathrm{RH}: 10,20$ \\
\hline$c e E K$ & 0.24 & 0.54 & \\
\hline$c e B I$ & 0.24 & 0.27 & \\
\hline$K E L * 7$ & 91.82 & 88.32 & \\
\hline$K E L^{*} 6$ & 8.18 & 11.68 & KEL6 \\
\hline
\end{tabular}


RHCE and KEL nucleotide positions

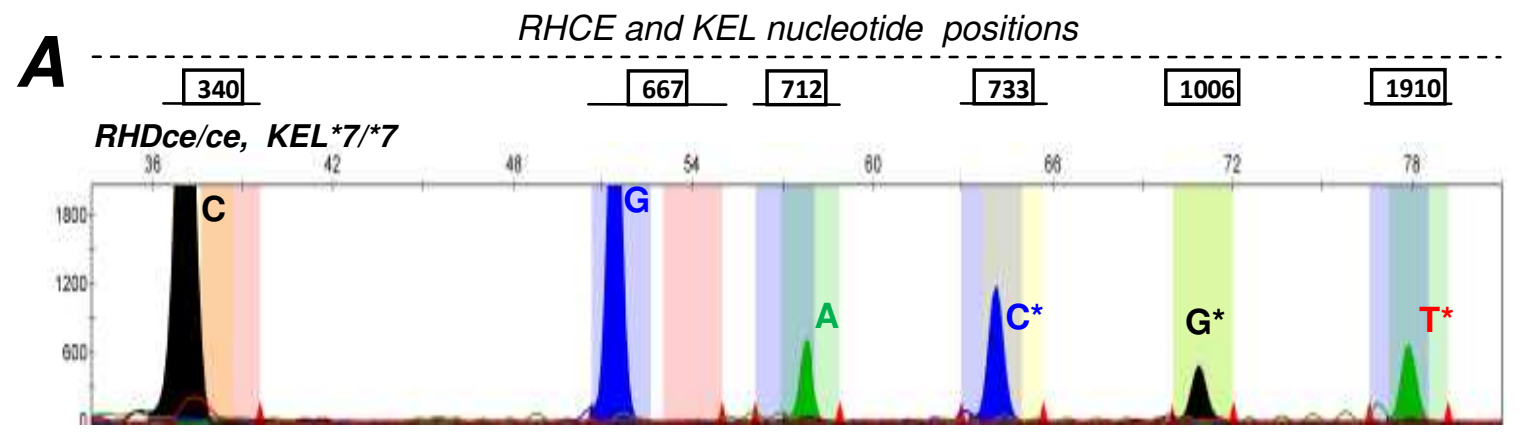

RHDce/(C)ce ${ }^{s}$ Type 1, KEL6/*7
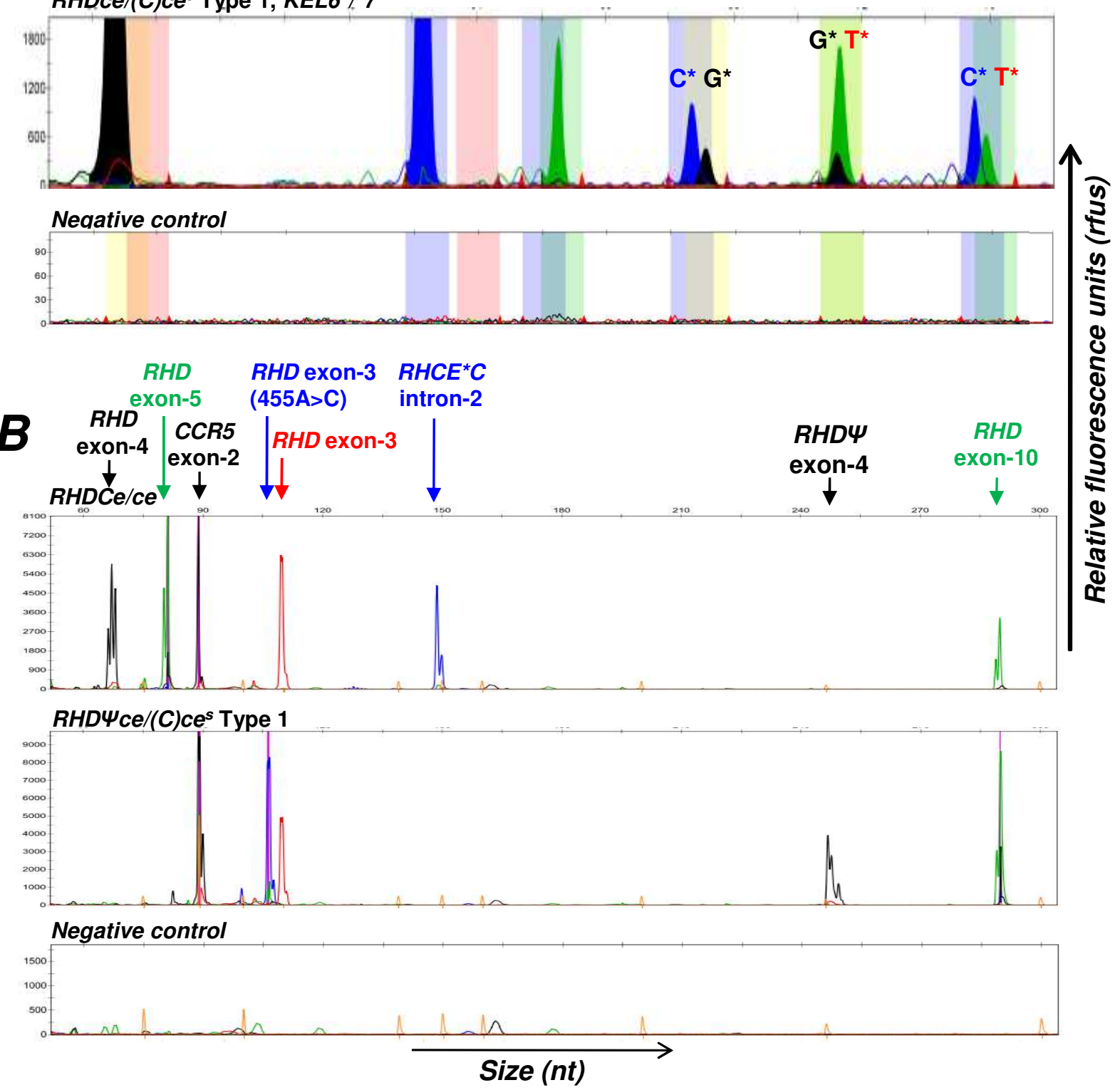